\title{
The Effects of Tajikistan's Accession to the Common Economic Space of Belarus, Kazakhstan, and Russia on Its Agricultural Sector Under Official and Depreciated Exchange Rates
}

\author{
Parviz Khakimov ${ }^{1}$, P. Michael Schmitz ${ }^{1}$ \& Ira Pawlowski ${ }^{1}$ \\ ${ }^{1}$ Department of Agricultural and Development Policy, Justus-Liebig University Giessen, Germany \\ Correspondence: Parviz Khakimov, Department of Agricultural and Development Policy, Justus-Liebig \\ University of Giessen, Senckenbergstr 3, Giessen 35390, Germany. E-mail: \\ Parviz.Khakimov@zeu.uni-giessen.de; parviz_khakimov@yahoo.com
}

Received: November 29, 2013 Accepted: February 17, 2014 Online Published: March 17, 2014

doi:10.5539/jsd.v7n2p133 URL: http://dx.doi.org/10.5539/jsd.v7n2p133

The research is financed by Volkswagen Foundation and German Academic Exchange Service (DAAD)

\begin{abstract}
Tajikistan is planning to join the Common Economic Space (CES) of Belarus, Kazakhstan, and Russia in order to benefit from free movement of capital, goods, especially the labour force. Labour migrants abroad are equivalent to 15 percent of country's population, 28 percent of the labour force, and 50 percent economically active population. Migrant remittances in Tajikistan are the main drivers of economic growth that induces currency appreciation. This paper, using a Partial Equilibrium Model, assesses the effects of Tajikistan's accession to the CES on the country's agricultural sector at official and depreciated (experimental) exchange rates. The latter enables testing the Marshall-Lerner Condition (MLC) and are calling to emphasize the cost of remittances-induced currency appreciation to producer, consumer, state budget, agricultural value added and balance of trade.

The overall welfare effects of CES accession on the agricultural sector are positive under both exchange rates. Producer and overall gain at depreciated exchange rate exceeds the gain at official exchange rate by 34 percent, while consumers gain almost 2.9 times less under depreciated exchange rate. Budget losses are 15 percent less at depreciated exchange rate rather than the official one. Producer and consumer gains, under both exchange rates, prevail over budget losses, therefore an overall gain will be ensured. The value of agricultural production in scenario, ceteris paribus, almost two times less at official exchange rate (14 percent) than under the depreciated one (27 percent). Furthermore, the deterioration balance of trade is smaller at depreciated exchange rate, thus, the MLC is met.
\end{abstract}

Keywords: Tajikistan, trade, welfare, agriculture, remittances, economic area, exchange rate, MLC

\section{Introduction}

Tajikistan is a small but liberal economy where agriculture plays a very important role. The agricultural sector as the engine of economy is affected by Tajikistan's commitments in global and regional trade agreements. Between 1985 and 2000 the agricultural sector has constituted more than 30 percent of the country's GDP. Within 2001-2011 the figure was close to 25 percent. The average growth rate of value-added in agriculture in 1997-2011 was 7 percent (WDI, 2012). Although the agricultural growth is shrinking within the last decade, it has still been important to ensure a stable overall economic growth of the country since 2000.

In the earlier 1990s, after the dissolution of the Soviet Union, trade reforms began and the state monopoly for international trade was abolished. In March 2013, after eleven years of negotiations Tajikistan became a full-fledged member of the WTO without any resources for a transition period (Note 1). In addition to its commitments in the WTO, Tajikistan is part of several other multilateral free trade agreements such as, the Commonwealth of Independent States (CIS), the Eurasian Economic Community (EurAsEC), the Economic Cooperation Organization (ECO), and the Central Asia Regional Economic Cooperation (Note 2). The country also has bilateral trade agreements with most CIS countries as well as Afghanistan, China, Iran, Pakistan, and 
Turkey. The main trading partners are Afghanistan, China, the European Union, Kazakhstan, Iran, the Russian Federation, and Turkey. As it was mentioned at the beginning, Tajikistan is currently planning to join the Common Economic Space (CES) of Belarus, Kazakhstan, and Russia. The CES is the successor of the EurAsEC (Note 3).

The impact of customs and trade unions on national economies is regularly analyzed. The Eurasian Development Bank (EDB) recently estimated the effect of Tajikistan's accession to the Custom Union and then CES by applying the general equilibrium model GTAP-GLOBE (EDB, April 2013). The findings of this study are: (a) in sum, the accession leads to positive effects to the countries' economies, with an insignificant positive effect in a short-run; (b) long-run positive effects would be higher if joining countries would use windows of opportunities. The main limitation of the EDB study, however, was the analysis of the countries of Tajikistan, Turkmenistan, and Uzbekistan as an aggregate region. According to the findings, the accession of the aggregate region to CES will positively affect the agricultural and mining sectors. Still, it is not clear how the aggregated study results are interpreted for each of the three countries. The impact on each country must be ambiguous depending on: the level of initial trade openness; the size of economy and its compositions; tariffs and taxes applied in international trade; and the price elasticity of demand for net export.

The present study analyses the effect of Tajikistan's accession to CES by applying a partial equilibrium model, in which Tajikistan is included as a single country. As reveal the analysis, remittances lead to an appreciation of the national currency. This effect has to be considered in any economic analysis. Thus, the model is simulated under the official and depreciated (experimental) exchange rates. The latter are calling to reveal the cost of remittances-induced currency appreciation to producer, consumer, state budget, agricultural value added and balance of trade. Furthermore, the depreciated (experimental) exchange rate enables testing the Marshall-Lerner Condition (MLC).

The objective of this paper is to assess the impact of Tajikistan's accession to CES on its agricultural sector. Precisely, this paper addresses three research questions: (a) How does the accession to CES effects consumers, producers and the state budget in Tajikistan? (b) How will agricultural value added and the balance of trade change? (c) What is the effect of experimental exchange rate depreciation on consumers, producers, state budget, as well as on agricultural value added and balance of trade?

\section{Methodology and Data Sources}

The main research tool for the analysis is a partial-equilibrium net trade model, called AGRISIM. The model builds on a GAMS interface and uses GAMS/CONOPT2 solver - a non-linear optimization package. AGRISIM is an ex-ante, non-linear, partial equilibrium, multi-market, and multi-region trade model.

The set of equations used in AGRISIM cover: supply and demand; seed and waste; feed and food demands; yield and area functions; calibration parameters and shift factors of abovementioned functions; total animal production in grain unit; net trade equation; prices (producer, consumer, border, producer incentive price); price transmission elasticity; market clearing; welfare function (consumer and producer surplus); rent for quota owners; equation of elasticity of supply, demand and income and its calibration parameters (Note 4). The equations of consumer and producer welfare changes in scenario for single country/region are provided in Khakimov (October 2013).

The AGRISIM model uses a multimarket approach that is widely used in CGE modeling, but the former deals with just one sector of an economy (agricultural), while the latter seeks equilibrium for a number of sectors. Being a partial equilibrium model, AGRISIM focuses on the agricultural sector only. As a dynamic component, the model allows the simulation of population and income growth with projections of agricultural production and subsequent agricultural trade surplus or deficit, ceteris paribus. While free trade is in place, this model allows identifying the gap between production and consumption and allocation of land under different crops, thus, it is serving as a basis for policy implication in order to minimize the gaps.

The AGRISIM model includes 18 countries/regions and the rest of the world (ROW). The 27 countries of the European Union are considered as one region (EU). The difference between the world and the 17 specific countries (including Tajikistan) plus 1 region (EU) are represented by ROW. The model includes 24 agricultural commodities (Note 5). After calculating the commodity groups, the final number of commodities included into AGRISIM's model 14.

The calculations are based on quantitative secondary data that are predominantly taken from FAOSTAT and from the OECD producer support estimate (PSE) databases. The producer and consumer agricultural support indicators for Tajikistan are discretely calculated, applying the OECD PSE approach (Khakimov, Pawlowski, \& 
Schmitz, 2014). The initial supply, demand, and income elasticities are taken from the SWOPSIM database. A new elasticity of supply is calculated using the initial elasticity, bounds and weights around the initial elasticity, commodity balances (domestic production, stock changes, net trade, feed use, seed use, waste, food demand, and statistical adjustment), total population in each country, producer prices, production quotas, subsidies (input, direct, general and single commodity transfer) and a multiplier for subsidies. New elasticities of demand and income are calculated using the initial elasticities, bounds and weights around them, commodity balances, and consumer prices.

In the model the shift factors are: yield, seed, feed, demand, waste, population and income growth, nominal rate of protection (NRP), retail margin, minimum farmgate price, production quota, exchange rate change (all changes in percentage per annum), border price to farm gate price transmission elasticity, as well as direct, input and general subsidies (in USD per ton).

The accession of Tajikistan to the CES is simulated in the model against a base scenario. The main shift factor in the model is the Nominal Rate of Protection (NRP). The NRP figures of the base scenario are calculated for each commodity and for all countries that are included in the model. In the simulated CES scenario all tariffs are zero.

In addition, the model includes two exogenous variables: population growth and exchange rate change. The consideration of population growth is important in Tajikistan, because it is substantial, so that affects domestic consumption patterns. Therefore, a more realistic pattern of changes in production, domestic consumption, and net trade can be reflected. In order to know the general effect of population growth, respective figures for all countries/regions of the model were included (Note 6). The second important issue considered in this study is the effect of labour migrant remittances on the Tajik Somoni (TJS) exchange rate. Calculation of a set of exchange rates clearly shows that during the last 6 years the national currency has appreciated due to the steady inflow of remittances. Therefore, two sets of scenarios were developed and simulated, one under the current official exchange rate and one with a 10 percent depreciation (experimental) exchange rate. The latter allows revealing the effect of remittances that caused the recent currency appreciation and testing of the Marshall-Lerner Condition (Note 7).

\section{Results}

The simulated scenarios reveal producer and consumer welfare changes as well as changes of the value of agricultural production and balance of trade due to Tajikistan's accession to the CES.

It can be generally concluded that the accession leads to an improvement in the welfare of both, producer and consumers compared to the base year under both, official and depreciated exchange rates. The effect on producer gains is significantly higher under a depreciated exchange rate: a ten percent depreciation of the national currency in foreign exchange leads to an increase of producer gains up to 34 percent compared to the situation at the official exchange rate. On the one hand the reverse situation can be expected in the case of consumers, i.e. their gains are 2.9 times higher at the official exchange rate than under depreciated exchange rate. On the other hand, one can logically expect a loss to the budget under the scenario of CES accession, under both exchange rates. Still, the loss to the budget is 15 percent less under a depreciated exchange rate than under the official exchange rate. Overall, there are gains to the country that are 34 percent higher under a depreciated exchange rate than under the official exchange rate (Figure 1).

Moreover, as the results show, the loss to budget and overall losses are less under a depreciated exchange rate than at the official exchange rate. But it is worth noting that under the depreciated exchange rate, overall, producer and consumer welfares will increase at a faster pace rather than under official exchange rate. The effect of producer and overall gains are more, while losses by consumers and in the budget are less under a depreciated exchange rate. The depreciation of the national currency ensures an increase in producer and a decrease in consumer welfares. The overall effect is smaller in simulated scenarios under the official exchange rate (Figure $1)$. 


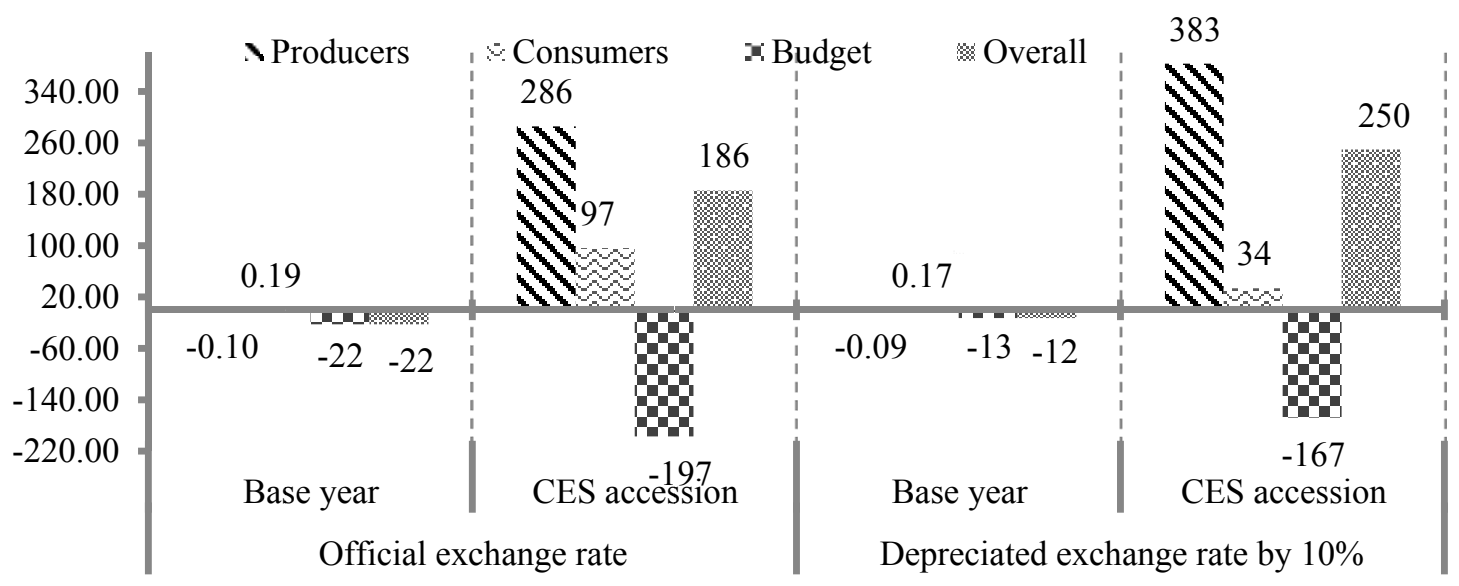

Figure 1. Welfare changes in scenario (Mio USD)

Source: own compilation based on AGRISIM simulation results.

Looking closer to the effect of Tajikistan's accession to the CES on the agricultural sector and its commodities: Total agricultural value-added and the volume of agricultural output will increase under CES accession compared to the base year. This is the case under both exchange rates, with the effect being higher under the depreciated exchange rate (27 percent) than under the official exchange rate (14 percent). Agricultural value-added will growth due to cotton, milk, oils, mutton \& goats, maize, and coarse grains output increases. In contrast, the production of wheat, rice, eggs, beef, and poultry decreases (Table 1).

Table 1. Value of production changes in scenario (000 USD)

\begin{tabular}{lcccccc}
\hline & \multicolumn{3}{c}{ Official exchange rate } & \multicolumn{3}{c}{ Depreciated exchange rate (10\%) } \\
\cline { 2 - 7 } & $\begin{array}{c}\text { Base year } \\
\text { (000 USD) }\end{array}$ & $\begin{array}{c}\text { CES accession } \\
(\text { O00 USD) }\end{array}$ & $\begin{array}{c}\text { CES/Base } \\
\text { year (\%) }\end{array}$ & $\begin{array}{c}\text { Base year } \\
(\text { 000 USD) }\end{array}$ & $\begin{array}{c}\text { CES accession } \\
\text { (000 USD) }\end{array}$ & $\begin{array}{c}\text { CES/Base } \\
\text { year (\%) }\end{array}$ \\
\hline Wheat & 122082 & 61376 & 50 & 110983 & 62314 & 56 \\
Coarse & 10940 & 13791 & 126 & 9945 & 14042 & 141 \\
Rice, refined & 53010 & 29071 & 55 & 48191 & 29405 & 61 \\
Oils & 150132 & 156054 & 104 & 136483 & 158299 & 116 \\
Sugar, refined & 0.294 & 0.302 & 103 & 0.267 & 0.307 & 115 \\
Milk & 116180 & 165038 & 142 & 105618 & 168209 & 159 \\
Beef \& veal & 60515 & 46270 & 76 & 55014 & 47293 & 86 \\
Pork & 1443 & 1630 & 113 & 1311 & 1665 & 127 \\
Poultry & 1093 & 448 & 41 & 994 & 463 & 47 \\
Maize & 24536 & 29533 & 120 & 22306 & 29873 & 134 \\
Soybean & 0,218 & 0,251 & 115 & 0,199 & 0,239 & 120 \\
Eggs & 8333 & 3668 & 44 & 7575 & 3724 & 49 \\
Mutton \& Goats & 67808 & 72894 & 108 & 61644 & 74853 & 121 \\
Cotton, fiber & 78199 & 209614 & 268 & 71090 & 212593 & 299 \\
Total & $\mathbf{6 9 4 2 7 1}$ & $\mathbf{7 8 9 3 8 7}$ & $\mathbf{1 1 4}$ & $\mathbf{6 3 1 1 5 5}$ & $\mathbf{8 0 2 7 3 3}$ & $\mathbf{1 2 7}$ \\
\hline
\end{tabular}

Source: own calculation and compilation based on AGRISIM simulation results.

The effects of Tajikistan's accession to CES have a negative effect on the balance of trade. In general, the worsening of the balance of trade should be expected because of population growth, which leads to domestic 
demand growth. However, the latter deteriorates to a lesser extent under a depreciated exchange rate than at official exchange rate. On commodity level, under a depreciated exchange rate, one should expect an improvement of the net trade situation for the commodities of coarse grain, milk, maize, and cotton. While on the other hand, a significant worsening of balance of trade can be expected for the commodities of wheat, rice, beef and veal, poultry, eggs, mutton and goats (Table 2).

Table 2. Balance of trade changes in scenario (000 USD)

\begin{tabular}{lcccc}
\hline & \multicolumn{2}{c}{ Official exchange rate } & \multicolumn{2}{c}{ Depreciated exchange rate (10\%) } \\
\cline { 2 - 5 } & Base year & CES accession & Base year & CES accession \\
\hline Wheat & -60147 & -112704 & -60147 & -111485 \\
Coarse & -1083 & -1157 & -1083 & -1086 \\
Rice, refined & 943 & -8605 & 943 & -7262 \\
Oils & -28031 & -28696 & -28031 & -28208 \\
Sugar, refined & -60404 & -71632 & -60404 & -70847 \\
Milk & -1044 & -5789 & -1044 & -550 \\
Beef \& veal & -17198 & -34527 & -17198 & -31332 \\
Pork & -6033 & -7491 & -6033 & -7233 \\
Poultry & -9489 & -13884 & -9489 & -13123 \\
Maize & -18 & 427 & -18 & 414 \\
Soybean & 0.22 & 0.25 & 0.22 & 0.24 \\
Eggs & -4662 & -8708 & -4662 & -8038 \\
Mutton \& Goats & 3 & -11796 & 3 & -7762 \\
Cotton, fiber & 146721 & 179819 & 146721 & 183401 \\
Total & $\mathbf{- 4 0 4 4 3 . 5}$ & $\mathbf{- 1 2 4 7 4 1}$ & $\mathbf{- 4 0 4 4 3 . 5}$ & $\mathbf{- 1 0 3 1 1 1}$ \\
\hline
\end{tabular}

Source: own calculation and compilation based on AGRISIM simulation results.

In general, CES accession has overall positive welfare effects compared to the base year under both exchange rates. It is worth noting that, however, the positive welfare effect of CES accession is lower than the effect of WTO accession (for comparison please refer to: Khakimov, October 2013). This provides affirmation that any import tariff reduction has overall positive welfare effects in a small open economy. This effect is larger under a depreciated exchange rate which, to some extent, expands domestic production and leads to an improvement of balance of trade (and so Marshall-Lerner condition is met).

\section{Discussion}

The discussion further will address some macroeconomic consequences of remittances-induced currency appreciation that leads producer, consumer and overall welfare changes, as well the cause of worsening/improving the state budget, agricultural value added and balance of trade.

During 2004-2012 remittances were important source of earning, foreign exchange and imports growth (imports exceeded exports by $2.5-3$ times). The economic development is stimulated mainly by domestic demand growth, due to the large volume of labour migrant remittances. Tajikistan is at the top of the list of countries (2007-2012) in terms of the ratio of remittances to GDP, which ranged between 35-49 percent (WDI, 2012). In 2012, according to data of the Federal Migration Services (FMS) of Russian Federation, the official number of Tajikistan's citizens in Russia made up 1.16 million (Note 8), that is equivalent to 15 percent of country population, 28 percent of the labour force, and 50 percent of the economically active population (Agency on Statistics [AS], Labour Market in Tajikistan, 2013).

Remittances are the main drivers of economic growth, private sector development, aggregate demand growth, interest rate change and alteration in fiscal policy. Remittances lead to rapid growth of some sectors of economy and might cause the appearance of the Dutch Disease in other sectors. The inflow of remittances may lead to 
currency appreciation and serve as an obstacle for real sector development. “.... remittance presents significant challenges for macroeconomic management. The inflow of remittances impedes monetary management and can rekindle inflationary pressures. Remittances contribute to the expansion of the trade deficit...they create a strong disincentive for domestic savings (IMF, January 2006)".

Currency appreciation/depreciation either due to inflow of remittances or other macroeconomic policy has ambiguous effect on tradable and non-tradable sectors. For the period 1990-2004 there was no significant gap between the value of exports and imports of goods and services in Tajikistan. But since 2005 onward, due to the steady inflow of remittances, on average import exceeds the export by 2.5 times (AS, Tajikistan in Figures, 2000 , 2005, 2009, 2013).

As theory suggests, depreciation of a country's currency against foreign currencies makes its exports cheaper and its imports more expensive. In other words, depreciation leads to expansion of exports and restriction of imports. In order to improve the trade balance, some countries depreciate domestic currency against the foreign currencies. The impact of a change in the exchange rate on the current trade balance means a test of the Marshall-Lerner Condition (MLC). In accordance with the MLC, a currency devaluation/depreciation will only lead to an improvement (move towards trade surplus) in the balance of trade, if the sum of price elasticities of demand (PED) for imports and exports (PED for net exports) is greater than one. Recently, the MLC was tested by Hsing (April, 2010) in studies of eight Asian countries (Note 9), the Kenyan economy by Caporale, Gil-Alana and Mudida (September, 2012), China by Fan et al. (2004) and Wu (2010). In each country (case), the MLC was met or rejected, depending on the sum of price elasticity of demand (PED) for net export being greater/less than one. Recently IMF study (2008) examined the response of trade balance to real exchange rate changes for the period 1990-2006 for 27 Middle Eastern and Central Asian countries. The study derived the trade balance elasticities with respect to the real effective exchange rate and showed that for a group of emerging market and low-income Middle Eastern and Central Asian countries (including Tajikistan), based on estimated elasticities, a 10 percent real depreciation is associated with a 1.2 percent of GDP trade balance improvement.

As was noted earlier, Tajik national currency (TJS) appreciated due to steady inflow of remittances. In this paper MLC is tested in order to reveal the influence of exchange rate depreciation on trades balance. In sum, Tajikistan's CES accession will lead to worsening of balance of trade under both official and depreciated exchange rates, due to population growth. But the worsening is less at depreciated exchange rate than under official exchange rate. In other words, under depreciated exchange rate the balance of trade will improve compared to the official exchange rate and the MLC will be met.

The literature survey reveals that there is no consensus among the researchers on whether remittances cause Dutch Disease. Palma (2005) identifies the four 'sources' of deindustrialization with one of them being the Dutch Disease (Note 10). Some other studies also suggest that remittances cause the appearance of Dutch Disease (for instance see: da Silva (July 2013); Acosta, Lartey \& Mandelman (August 2009); Makhlouf and Mughal (June 2011); Edsel (June 2010) and (Note 11)). On the contrary some other studies confirm the lack of relationship (Makhlouf \& Mughal (June 2011); Edsel (June 2010) and (Note 12)). In case of Pakistan, for instance, Makhlouf and Mughal (June 2011) found that, aggregate remittances from Persian Gulf contribute to the Dutch Disease, those from North America and Europe do not. Da Silva (July 2013) stated that Dutch Disease in Brazil occurs in relative terms. Using a small open economy model, Barajas et al (December 2010) shows that standard "Dutch Disease", which caused by appreciation, are substantially weakened or even overturned depending on: (a) degree of openness; (b) factor mobility between domestic sectors; (c) counter cyclicality of remittances; (d) the share of consumption in tradable; (e) and the sensitivity of a country's risk premium to remittance flows.

While Dutch Disease is in place, prices for internationally traded commodities will fall, because domestic currency will appreciate, with no immediate changes on domestic real economic productivity. Consequently, as a next effect, domestic and export oriented tradable sector face a fall in productivity.

In order to define, whether remittances cause of appearances of Dutch Disease and an appreciation of exchange rate, Acosta et al. (August 2009) in own theoretical model, consider three cases: (a) where remittances are exogenously determined; (b) where remittances are countercyclical and; (c) where remittances act like capital inflows. Their findings generally suggest that remittances inflow leads to the realization of the Dutch Disease phenomenon under each considered cases.

Some studies offer methods for reducing remittance shocks by using appropriate countervailing measures that allow enhancing and ensuring the overall productivity of an economy. For instance, Lopez, Molina and Bussolo (April 2007) believe that "a reduction of payroll taxes is a better alternative policy tool to limit the negative 
labour supply response following a remittance shock". But such measure is helpful only if a labour shortage is observed in the domestic labour market.

Steady inflow of remittances leads to an increase of the demand for tradable and non-tradable commodities. "So far the prices of tradable commodities are determined by the international market an increase in demand exerts pressure only on the prices of non-tradable commodities. A new equilibrium will be achieved by resource shifting from tradable sector to favour of non-tradable sector (Edsel, June 2010)." Remittances-induced currency appreciation will negatively affect the export because domestically produced commodities become less competitive in domestic and international market. The remittance flow leads to a decline in labour supply in tradable sector and consumption demand increases in favour of the non-tradable sector. An increase of non-tradable prices, which is consistent with real exchange rate appreciation, consequently creates an expansion of non-tradable sector at the expense of the tradable sector (Acosta et al., August 2009). How does the labour supply on tradable/non-tradable sector change due to steady inflow of remittances in Tajikistan? As the analysis reveals, during 2004-2010 in Tajikistan the employment level dropped neither in tradable nor non-tradable sectors. Only in 2010 (post economic crisis period) an increase of 10 percent of employment in non-tradable sector and small positive changes of employment in tradable sector was observed (AS, Labour Market in Tajikistan, 2013). These 10 percent employment increases in non-tradable sector can be explained by a faster increase of the consumer price index (CPI) for non-tradable commodities than tradable one (AS, Prices in Tajikistan, 2012). Inflow of remittances leads to household income growth and consumption of non-tradable goods. Remittances are the cause of a decrease/increase of labour supply on tradable/non-tradable sectors and price increase (thus, production costs) on non-tradable sector (Acosta et al., August 2009). What is behind the weak and/or lack of response on employment shifts in tradable and non-tradable sectors due to economic decline/growth caused by remittances in Tajikistan? As theory suggests, economic decline/growth leads to labour demand decreases/increases. However, figures on employment in Tajikistan are almost unresponsive to economic decline/growth which can be explained by high level of informal employment and informal (shadow) economy. In Tajikistan the size of shadow economy in 2007 was 41 percent (Schneider, March 2012). In 2008, Abdih and Medina (IMF, May 2013) reported that the size of informal economy is 32.8 percent of GDP (Note 13). Based on the existence of external labour migration, informal employment, and shadow economy it can be stated that during the economic crisis (2008-2009) the labour demand fold (at the expense of employed in the informal sector) and that the demand only started to increase again, since 2010. Thus, the official figures on labour force (employed, unemployed, and economically inactive population) do not allow proving or rejecting the existence of a relationship between the inflow of remittances and the drop of employment in manufacturing and agricultural sectors and its growth in the non-tradable sector.

This study shows that, as a whole, remittances play an ambiguous role in the development of different sectors of the economy. On one hand, they cause a growth of some sectors (transportation, construction, trade, financing, etc.), while on the other hand, they serve as an obstacle to development of real sectors of the economy (manufacturing and agriculture). Poverty reduction, growth of the transport sector, the construction boom in the private sector, growth of the trade sector, an increase in aggregate demand, reduction of the level of unemployment and less tension in domestic labour market, an increase in the paying capacity of the population are among the positive effects of labour migration and inflow of remittances. The negative effects of labour migration and remittances are the effect of foreign purchases (the excess of imports over exports), high inflation level, stagnation of some sectors of economy and appearance of Dutch Disease symptoms, the strengthening of the national currency, increasing consumer price indices, interest rate growths during the economic boom, etc.

Future studies should assess the impact of remittances on other macroeconomic indicators and the appearance of Dutch Disease in different sectors of economy. The literature survey reveal that in Tajikistan the household-receivers of labour migrant remittances are less incentive to offer own services in domestic labour market than households without labour migrants (Justino \& Shemyakina, October 2010). Based on that it can be concluded that Dutch Disease might effects the domestic labour market, while the next step is to prove the appearance of Dutch Disease (or already is in place) in real sectors of the economy (manufacturing and agricultural). All above is a theoretical assumption which requires further empirical confirmation. Therefore, the remittance effect on macroeconomic level and prove/disprove of the appearance of Dutch Disease in sectors of economy are subject of further studies. For a while, it can be stated that remittances cause an appreciation of exchange rate and thus serve as an obstacle for development of the manufacturing and agricultural sectors.

Finally, it is important to address some study related and general limitations of any modelling technique. First, it is not possible to reveal the effects of production increase for those commodities that have not been produced before, i.e. for sugar and soybean in this study, in case of Tajikistan. Second, any modelling technique does not 
allow applying one tariff within one economic community and at the same time apply other common tariffs in trade with rest countries. Third, due to the unavailability of elasticity figures (supply, income and demand) for some commodities (table grapes and raisin, apricot and dried apricot, tomatoes, potatoes, onions and apples) in which Tajikistan has a comparative advantage, it was not possible to include them into the model. Calculation of elasticities figures for all countries and above mentioned commodities, in general, is beyond the scope of this study and therefore, including them into the model is the subject of further studies. Finally, no PE model enables revealing the shift in other sectors of economy due to a change in one single sector. The possibility to apply a CGE model and to use other shift factors in counterbalance to remittances-induced appreciation is subject to further studies and depends on the availability of necessary data.

\section{Conclusion}

Agriculture plays a significant role in the economic growth of Tajikistan. This study analysed the impact of Tajikistan's accession to the Common Economic Space (CES) taking into account the effect of labour migrant remittances that lead to exchange rate changes. Hence, in this paper special attention was paid to the issue of exchange rate change. Two sets of CES accession scenarios, one under official exchange rate and one with a 10 percent depreciated (experimental) exchange rate were developed and simulated. The general importance of population growth on real economic developments in Tajikistan, it was also considered in the analysis. As a whole, the simulated scenario allows assessing supply and demand changes, balance of trade changes, producer and consumer welfare changes, state budget changes, and producer and consumer effects by policy option in the agricultural sector.

The effect of the country's accession to the CES has a positive effect on both, producers and consumers, with substantial losses to the budget. The producer gains exceed the losses of consumers under both exchange rates, with a higher net effect under depreciated exchange rate. However, producer and consumer gains prevail over budget losses and therefore an overall gain will be ensured. Thus, the gain of gainers exceeds the loss of losers and the Kaldor-Hicks criterion (Note 14) is met.

Based on the study findings it can be stated that the decline/increase on the value of agricultural production will be in slower/faster pace under a 10 percent depreciation of the exchange rate than under the official exchange rate.

In this paper the scenario of CES accession is simulated under depreciated (experimental) exchange rate, ceteris paribus, i.e. regardless the effect of experimental exchange rate depreciation to other macroeconomic variables such as business cycles, fiscal policy, inflation, output (GDP), and interest rate. For now, the theoretical conclusion is that the overall economic effect of currency depreciation will be positive because the price elasticity of demand for net trade is greater than one and for whole economy the MLC will be met. Empirical confirmations of the effect of exchange rate depreciation on aforementioned macroeconomic variables are subjects of further studies.

Simulated scenarios under official and depreciated exchange rates clearly show that the balance of trade will deteriorate compared to the base year, but the deterioration will be less under the depreciated exchange rate. The latter means that currency depreciation leads to an improvement of current account balance and the Marshall-Lerner Condition (MLC) is met. This study reveals that currency depreciation will lead to an improvement of current account balance, thus positively influence the agricultural sector.

This study shows that, as a whole, remittances play an ambiguous role in the development of different sectors of the economy on macro and micro level. On the one hand, remittances can become a cause of growth to some sectors, while on the other hand, they might serve as an obstacle to development for other, real sectors of the economy.

\section{Acknowledgements}

This paper is a part of the LUCA (Land Use, Ecosystem Services and Human Welfare in Central Asia) project financed by Volkswagen Foundation. The paper has benefited from financial support of Volkswagen Foundation and German Academic Exchange Service (DAAD). These supports are gratefully acknowledged.

We are grateful to anonymous referees for extremely useful and constructive comments.

\section{References}

Acosta, P. A., Lartey, E. K. K., \& Mandelman, F. S. (August 2009). Remittances and the Dutch Disease, Federal Reserve Bank of Atlanta, Working Paper 2007-8a. 
Agency on Statistics under the President of the Republic of Tajikistan (AS) (2005, 2010 \& 2012). Agriculture sector in Tajikistan.

AS. Tajikistan in Figures. (2000, 2005, 2010 \& 2013).

AS. Labour Market in Tajikistan. (2007 \& 2013).

AS. Prices in Tajikistan. (2012).

Barajas, A., Chami, R., Hakura, D. S., \& Montiel, P. (December 2010). Workers' Remittances and the Equilibrium Real Exchange Rate: Theory and Evidence. Middle East and Central Asia Department and IMF Institute, IMF Working Paper WP/10/287. Retrieved from http://www.imf.org/external/pubs/ft/wp/2010/wp10287.pdf

Caporale, G. M., Gil-Alana, L. A., \& Mudida, R. (September 2012). Testing the Marshal-Lerner Condition in Kenya. Discussion Paper, DIW Berlin. Retrieved from http://papers.ssrn.com/sol3/papers.cfm?abstract_id=2160769

Edsel, L., \& Beja, Jr. (June 2010). Do international remittances cause Dutch Disease? MPRA Paper No. 23022, Retrieved from http://mpra.ub.uni-muenchen.de/23022/1/MPRA_paper_23022.pdf

Eurasian Bank of Development (EDB). (April 2013). Economic effect assessment of Tajikistan accession to the Custom Union and Common Economic Space (in Russian). Retrieved from http://www.eabr.org/general//upload/CII\%20-\%20izdania/Proekti\%20i\%20dokladi/Tadjikistan-CU-SES/EB D_Centre_Doklad_14_RUS_1.pdf

Fan, J., Zheng, Q., Wang, Y., Yuan, X., \& Liang, J. (2004). Does the Marshal-Lerner condition held in China. Brussels. Retrieved from http://www.iioa.org/conferences/intermediate-2004/pdf/389.pdf

Hsing, Y. (April 2010). Global economic review: Perspectives on East Asian economies and industries. Retrieved from http://www.tandfonline.com/doi/pdf/10.1080/12265081003696429\#.UpczmMSkpv8

International Monetary Fund (IMF). (January 2006). The Macroeconomics of Remittances: The Case of Tajikistan. Prepared by Alexei Kireyev. Policy Development and Review Department. IMF Working Paper WP/06/2. Retrieved from http://www.imf.org/external/pubs/ft/wp/2006/wp0602.pdf

IMF. (2008). Trade Elasticities in the Middle East and Central Asia: What is the Role of Oil? Retrieved from http://www.imf.org/external/pubs/ft/wp/2008/wp08216.pdf

IMF. (May 2013). Measuring the Informal Economy in the Caucasus and Central Asia. IMF WP/13/137. Prepared by Abdih Y. \& Medina L. Retrieved from http://www.imf.org/external/pubs/ft/wp/2013/wp13137.pdf

Justino, P., \& Shemyakina, O. N. (October 2010). Remittances and Labor Supply in Post-Conflict Tajikistan. MICROCON Research Working Paper 35. Retrieved from http://www.microconflict.eu/publications/RWP35_PJ_OS.pdf

Khakimov, P. (October 2013). The impact of WTO accession on agricultural sector of Tajikistan. International Conference and Young Researchers Forum - Natural Resource Use in Central Asia: Institutional Challenges and the Contribution of Capacity Building. Center for International Development and Environmental Research, University of Giessen (JLU Giessen). Retrieved from http://ageconsearch.umn.edu/handle/152245/simple-search?query=Khakimov

Khakimov, P., Pawlowski, I., \& Schmitz, P. M. (2014). Measuring Agricultural Support for Tajikistan. Journal of Agricultural Science. Vol. 6. http://www.ccsenet.org/journal/index.php/jas/issue/view/1020

Lopez, H., Molina, L., \& Bussolo, M. (2007). Remittances and the real exchange rate. World Bank Policy Research Working Paper 4213

Makhlouf, F., \& Mughal, M. (June 2011). Remittances, Dutch Disease, and Competitiveness - A Bayesian Analysis. Centre d'Analyse Théorique et de Traitement des données économiques. CATT WP No. 1, September 2011. Retrieved from http://www.univ-pau.fr/live/digitalAssets/106/106591_2011_2012_1DocWRemittances DutchDiseaseCompetitivenessBayesianAnalysisFMakhloufMMughal.pdf

Palma, G. (2005). Four Sources of "De-Industrialisation" and a New Concept of the "Dutch Disease". In J. A. Ocampo (Ed.), Beyond Reforms: Structural Dynamics and Macroeconomic Vulnerability. New York: Stanford University Press and World Bank.

Schneider, F. (March 2012). The Shadow Economy and Work in the Shadow: What Do We (Not) Know? IZA DP No. 6423. Retrieved from http://ftp.iza.org/dp6423.pdf 
da Silva, J. A. (July 2013). Deindustrialization and Dutch Disease: the case of Brazil. Retrieved from http://www.tnc-online.net/pic/20130711080450913.pdf

World Bank. (2012). World Development Indicators 2013. Retrieved from http://data.worldbank.org/data-catalog/world-development-indicators

Wu, Y. (2010). Revisiting the Marshall-Lerner Condition under Processing Trade - Empirical Evidence from China. Beijing, China. Retrieved from http://www.rcie-cn.org/conferences/2010/papers/wu_ying.pdf

\section{Notes}

Note 1. Tajikistan applied for WTO membership on the $29^{\text {th }}$ of May 2001. After eleven years of negotiations, on the $10^{\text {th }}$ of December 2012 the General Council paved the way for Tajikistan's membership in the WTO by approving its accession package. The parliament (Majlisi Milli) of the Republic of Tajikistan, on the $9^{\text {th }}$ of January 2013, ratified the accession and the country became a full-fledged member of the WTO on the $2^{\text {nd }}$ of March 2013. The current weighted average tariff for agricultural products in Tajikistan under the WTO is 10.4 percent, which is 2.6 percent higher than the common tariff within the CES. It is worth noting that all tariffs within the CES are zero while 7.8 percent for agricultural products are applied on trade with the rest of the world.

Note 2. CAREC program includes Afghanistan, Azerbaijan, the People's Republic of China, the Republic of Kazakhstan, the Kyrgyz Republic, Mongolia, Tajikistan, and Uzbekistan.

Note 3. In 1995, the process of discussion of the Eurasian Economic Community (EurAsEC) started. The EurAsEC has five member states: Russia, Belarus, Kazakhstan, Kyrgyzstan, and Tajikistan. The agreement on creation was signed by the leaders of these countries on 10th October 2000 and came into effect on $1^{\text {st }}$ May 2001 after ratification by parliaments of all member states. The next stage of economic integration of Post-Soviet countries was the creation of the Custom Union (CU) between Belarus, Kazakhstan and Russia that began on $6^{\text {th }}$ of October 2007. Within the EurAsEC applied tariffs for imports are zero. Within the Custom Union in trade with third countries the average common custom tariff applied was 10.5 percent. After the WTO accession of Russia this tariff within the Custom Union fell to 7.8 percent. The Common Custom Code came into force on $6^{\text {th }}$ July 2010 and the Common Economic Space (CES) started to function on $1^{\text {st }}$ July 2011. The next stage of integration would be the creation of the Eurasian Union (expected in 2015). Russia, Belarus, and Kazakhstan plan to harmonize the treaty establishing the Eurasian Union - an association that should crown the integration process so far, the intermediate stages of the Customs Union (CU) and the Common Economic Space (CES). Kyrgyzstan started the process of discussion accessing the Common Economic Space and then the Eurasian Union. Tajikistan, just after the full-fledged membership of Kyrgyzstan, has a chance to become a member state because the former does not have a common border with the three already mentioned members of this regional economic integration.

Note 4. The other equations used in this paper will be available upon request from the authors.

Note 5. Groups of commodities are calculated as poultry (chickens, ducks, geese, turkey and other poultry), coarse grains (rye, barley, oats), oilseeds (rapeseed, soybean, sunflower and cottonseed) and mutton and goats (MUTG). The remaining commodities included in AGRIDATA are: wheat, maize, milk, beef and veal, pigmeat (pork), eggs, soybean, cotton, sugar and rice.

Note 6. For the Rest of the World (ROW) a weighted average annual growth figure was calculated and then included into the model.

Note 7. The Marshall-Lerner Condition (MLC) deals with the relationship between the exchange rate and the balance of payments. The Marshall-Lerner condition is named after the English economist Alfred Marshall (1842-1924) and the Romanian born economist Abba Lerner (1905-1985).

Note 8 It worth not that, however, not all Tajik citizens arrived to Russia are labour migrants and Russia just destination country of 90 percent of Tajik labour migrants.

Note 9. The countries are: Hong Kong, India, Japan, Korea, Malaysia, Pakistan, Singapore, and Thailand.

Note 10. The four sources of deindustrialization according to Palma (2005) are: (a) an inverted-U relationship between manufacturing employment and income per capita; (b) declining relationship (over time) between incomes per capita and manufacturing employment; (c) changes in the level of income per capita at which the share of manufacturing employment is expected to decline; (d) Dutch Disease could be considered an additional form of deindustrialization. 
Note 11. In case of middle-income countries.

Note 12. In case of upper and low-income countries.

Note 13. Abdih and Medina (IMF, May 2013) defined the relative contribution of cause to the size of the informal economy: (1) Tax Burden - 11.7\%; (2) Labour Rigidities - 0.0\%; (3) Institutional Quality - 47.6\%; (4) Regulatory Burden in Financial and Product Markets - 40.7\%.

Note 14. Named after Nicholas Kaldor and John Hicks, also known as Kaldor-Hicks efficiency. They state that an outcome is efficient if the gain of gainers exceeds the loss of the losers; in welfare economics, this is known as the Kaldor-Hicks criterion.

\section{Copyrights}

Copyright for this article is retained by the author(s), with first publication rights granted to the journal.

This is an open-access article distributed under the terms and conditions of the Creative Commons Attribution license (http://creativecommons.org/licenses/by/3.0/). 